\title{
Praktik Penyembelihan dan Pengolahan Ayam di Rumah Potong Ayam Kecamatan Polewali (Tinjauan Undang-Undang Nomor 33 Tahun 2014 tentang Jaminan Produk Halal)
}

\author{
Suardi Kaco, Nur Fitriana \\ Prodi Hukum Ekonomi Syariah, Fakultas Agama Islam, Universitas Al Asyariah Mandar \\ rahmah_muin@mail.unasman.ac.id
}

\begin{abstract}
Abstrak
Penelitian ini merupakan penelitian lapangan yang bertujuan untuk mengetahui praktik penyembelihan dan pengolahan ayam di rumah potong ayam di kecamatan Polewali serta mengetahui bagaimana tinjauan undang-undang nomor 33 tahun 2014 tentang jaminan produk halal terhadap praktik penyembelihan dan penolahan ayam di kecamatan polewali. Lokasi penelitian ini bertempat di pasar sentral pekkabata kecamatan polewali. Hasil penelitian menunjukkan bahwa praktik penyembelihan dan pengelolahan ayam di rumah potong ayam pasar sentral memiliki tahapan yaitu: pengambilan ayam dari kandang, mengambil ayam satu per satu untuk disembelih, membaca "Bismillah" dalam hati dan ayam disembelih dibagian leher, menggunakan pisau yang tajam, tahap pengolahan ayam setelah disembelih yaitu: perendaman ayam di air panas yang tidak mendidih, pencabutan bulu menggunakan mesin bubut pencabut bulu ayam, pengeluaran jeroan atau organ dalam, pencucian ayam, pemotongan daging ayam dan pengemasan daging ayam. Penyembelihan dan pengolahan ayam di pasar Sentral Pekkabata Kecamatan Polewali masih banyak belum sesuai dengan Undang-Undang Nomor 33 Tahun 2014. Karena semua rumah pemotongan hewan yang ada di Kabupaten Polewali Mandar belum mempunyai sertifikat halal. Dan mengenai syarat yang harus dipenuhi untuk penyembelihan halal menurut Peraturan Pemerintah Nomor 95 Tahun 2012 Tentang Kesehatan Masyarakat Veteriner dan Kesejahteraan Hewan disebutkan dalam pasal 8 dan pasal 9 masih ada rumah potong ayam yang belum menerapkan hal demikian. Selain itu dalam proses pengolahan ayam, ke empat rumah potong ayam di Pasar Sentral Pekkabata Kecamatan Polewali tidak adanya pemisahan antara ayam yang gagal disembelih dan yang berhasil disembelih. Dan ke empat rumah potong ayam di pasar Sentral Pekkabata Kecamatan Polewali dalam proses penyembelihan dan pengolahan ayam masih dilakukan disatu lokasi dimana tidak ada pembagian antara daerah kotor dan daerah bersih.
\end{abstract}

Kata Kunci: penyembelihan, pengolahan ayam, rumah potong ayam

\section{PENDAHULUAN}

Polewali Mandar merupakan salah satu Kabupaten yang ada di Sulawesi Barat dan merupakan daerah penghasil tanaman pangan. Kawasan tersebut dibagi menjadi tiga kawasan diantaranya kawasan budidaya ternak besar (Kecamatan Binuang, Matakali, Anreapi, Wonomulyo, Mapilli, Tapango, Bulo, Campalagian, Tubbi Taramanu dan 
Matangnga), kawasan budidaya ternak kecil (Kecamatan Luyo, Campalagian, Balanipa, Tinambung, Limboro, Alu dan Tubbi Taramanu), dan kawasan budidaya ternak unggas (Kecamatan Binuang, Matakali, Wonomulyo, Campalagian, Tinambung dan Limboro). Kesesuaian lahan untuk peternakan hanya mengacu pada kelas kesesuaian lahan untuk padang pengembalaan (pasture), hal ini disebabkan komoditas peternakan tidak menghendaki persyaratan tanah dan iklim yang spesifik. Kabupaten Polewali Mandar memiliki potensi pengembangan ternak besar maupun ternak kecil dan unggas khusus untuk ternak besar pemasarannya melalui perdagangan antar pulau, sedangkan ternak kecil sebagai konsumsi lokal.

Hewan ternak adalah hewan yang sengaja dipelihara sebagai sumber pangan, sumber bahan baku, atau sebagai pembantu pekerjaan manusia. Hewan ternak dapat berupa hewan apa pun (termasuk serangga dan vertebrata tingkat rendah seperti ikan dan katak). Di kehidupan sehari-hari orang biasanya merujuk kepada unggas dan mamalia domestik, seperti ayam, angsa dan itik untuk unggas, serta kambing, domba, kuda, atau keledai untuk mamalia. Berdasarkan hasil observasi yang dilakukan di kecamatan Polewali, salah satu hewan ternak paling banyak adalah unggas ayam. Sehingga pengolahan ayam di Polewali sangat banyak dimanfaatkan dibidang produksi.

Makanan mempunyai peranan yang penting bagi manusia dalam kehidupan seharihari. Dalam hal ini yaitu untuk mempertahankan kelangsungan hidup, melindungi dan menjaga kesehatan serta sebagai sumber energi. Adapun makanan dan minuman yang dikonsumsi haruslah halal dan baik, itu akan memiliki pengaruh yang baik pula bagi manusia yang mengonsumsinya. Demikian halnya dengan makanan yang haram dan tidak baik, akan berpengaruh yang tidak baik pula bagi manusia yang mengonsumsinya.

Islam telah mengatur tentang makanan mana yang dihalalkan dan mana yang diharamkan. Bahan makanan yang dibutuhkan oleh tubuh manusia salah satunya adalah protein yang diperoleh dari ikan dan daging hewan. Hewan yang halal dan baik ditentukan juga pada saat proses penyembelihan dan pengolahannya. Penyembelihan adalah sengaja memutus saluran makanan, tenggorokan dan dua pembuluh darah hewan dengan alat yang tajam selain kuku dan gigi. Penyembelihan dimaksudkan untuk melepaskan nyawa hewan dengan jalan paling mudah, yang kiranya tidak menyakiti hewan tersebut. Tata cara penyembelihanpun sangat berpengaruh pada kehalalan hewan tersebut, karena penyembelihan yang tidak sempurna akan mengakibatkan hewan tersebut disamakan dengan bangkai, sedangkan Allah mengharamkan memakan bangkai. Hal tersebut dijelaskan dalam Pasal 18 Undang-Undang Nomor 33 Tahun 2014.

Di Pasal tersebut dijelaskan bahwa setiap hewan yang akan diedarkan untuk selanjutnya diolah sebagai produk, harus disembelih sesuai dengan syari'at Islam. Pasal itu memuat tentang ketentuan umum jaminan kehalalan suatu produk. Aturan-aturan tersebut yaitu tentang standarisasi kehalalan, baik dalam produk makanan, minuman, obat, kosmetik, produk kimiawi, produk biologi, produk rekayasa genetik, serta barang gunaan yang dipakai, digunakan, atau dimanfaatkan oleh masyarakat. Dalam undang-Undang tersebut disebutkan bahwa setiap produk yang beredar di Indonesia harus bersertifikasi halal. Begitu juga dengan penyembelihan hewan.

Dari observasi yang dilakukan di Kecamatan Polewali khususnya di pasar Sentral Pekkabata, diketahui bahwa terdapat kurang lebih 10 rumah potong ayam yang mempunyai 
peran besar bagi tersedianya pasokan daging ayam bagi masyarakat Kecamatan Polewali. Rumah potong hewan termasuk rumah potong ayam juga harus bersertifikasi halal agar daging ayam yang nantinya akan dikonsumsi oleh konsumen telah benar-benar halal dan tayyib. Nyatanya rumah potong ayam yang bersertifikasi halal masih minim dan masih banyak pengelolah rumah potong ayam tidak mengetahui standar kehalalannya, baik dari cara penyembelihan hingga pengolahannya.

Sehubungan dengan hal itu, masih banyak produk yang beredar di masyarakat belum semua terjamin kehalalannya. Akan tetapi, peraturan perundang-undangan yang memiliki keterkaitan dengan pengaturan Produk Halal belum memberikan kepastian dan jaminan hukum bagi masyarakat muslim. Sebab itulah, pengaturan mengenai Jaminan Produk Halal perlu diatur dalam satu undang-undang yang secara komprehensif mencakup Produk yang meliputi barang dan/atau jasa yang terkait dengan makanan, minuman, obat, kosmetik, produk kimiawi, produk biologi, dan produk rekayasa genetik serta barang gunaan yang dipakai, digunakan, atau dimanfaatkan oleh masyarakat, termasuk juga rumah potong ayam yaitu dalam Undang-Undang Nomor 33 Tahun 2014 tentang Jaminan Produk Halal tersebut.

Seiring dengan perkembangan zaman yang semakin modern yang ditandai semakin pesatnya industrialisasi dan teknologi mutakhir, maka segala sarana yang diperlukan manusia juga semakin canggih dan kompleks. Hal ini juga berpengaruh terhadap perkembangan tata cara penyembelihan hewan, sehingga muncul beragam model penyembelihan. Meningkatnya kebutuhan akan daging ayam, banyak orang melirik usaha penyembelihan, karena dianggap menguntungkan serta pemotongannya sederhana, apalagi banyak rumah makan dan restauran yang memasok daging ayam dari para rumah potong ayam. Karena itulah banyak pengelola rumah potong ayam tidak mengetahui secara pasti tata cara penyembelihan sesuai dengan syari'at Islam. Yang terpenting ayam yang disembelih sudah mati tanpa melihat apakah ayam itu benar-benar mati sempurna atau belum.

\section{TINJAUAN PUSTAKA}

\section{A. Defenisi Penyembelihan dan Pengolahan Ayam}

Penyembelihan merupakan tindakan memutus empat urat yang pada hewan diantaranya tenggorokan, kerongkongan dan dua urat yang di bagian samping leher. Letak dan posisi pemotongan dapat dilakukan di bagian atas leher atau di bagian bawah leher, atau dalam situasi yang tidak memungkinkan dilakukannya penyembelihan dileher, akan dilakukan penikaman yang mematikan dibagian mana saja dari tubuh hewan itu. ${ }^{1}$

Menyembelih ialah melenyapkan ruh binatang dengan cara memotong leher kerongkongan dan tenggorokan serta dua urat nadi dengan alat yang tajam, kecuali gigi dan tulang atau cara lain yang dibenarkan oleh syariat Islam. ${ }^{2}$ Hewan yang tidak disembelih merupakan hewan yang hukumnya haram untuk dimakan karena status hewan itu sama

\footnotetext{
${ }^{1}$ Wahbah al-Zuhaili, Fiqih Islam Wa Adillatuhu, jilid 4, (Cet. 10; Damaskus: Darul Fikr, 2007), h. 304-305.

${ }^{2}$ Rohadi Abdul Fatah, Pedoman dan Tata Cara Pemotongan Hewan Secara Halal, (Cet. III; Jakarta: Direktur Urusan Agama Islam dan Pembinaan Syari’ah, 2010), h. 19
} 
halnya dengan bangkai. Sementara itu, hewan yang disembelih harus binatang yang halal dan boleh untuk dimakan, misalnya sapi, kerbau, kambing, dan ayam. Jika binatang yang disembelih itu binatang haram, seperti babi maka meskipun disembelih dengan mengatas namakan Allah, binatang itu tetap haram hukumnya untuk dimakan. Dengan kata lain, hewan itu tidak berubah menjadi halal meskipun telah dipotong atau disembelih secara syar'iah.

Ada dua macam penyembelihan, yaitu menyembelih hewan yang telah dikuasai dan menyembelih hewan yang tidak dikuasai. Penyembelihan hewan dengan maksud dikuasai yaitu dengan cara memotong jalan makan, jalan nafas, menusuk bawah tenggorok dan tempat kalung. Adapun maksud dari penyembelihan hewan yang tidak dikuasai yaitu hewan yang diperoleh atau didapatkan dengan cara berburu menggunakan senjata atau dengan menombak hewan tersebut.

Hewan yang boleh dimakan dagingnya oleh manusia tidak halal dimakan kecuali dengan penyembelihan dengan syara' atau dengan cara semakna dengannya. Ada dua binatang yang dikecualikan oleh syariat Islam dari ketegori bangkai, yaitu belalang dan ikan dengan semua jenisnya dari berbagai macam binatang yang hidup di dalam air. ${ }^{3}$

Hewan yang gagal dalam proses penyembelihan tidak baik untuk dikonsumsi. Artinya, hewan tersebut tidak halal tanpa proses penyembelihan. ${ }^{4}$ Yang dimaksud dengan kata ini adalah: penyembelihan hewan atau memotongnya dengan jalan memotong tenggorokannya, atau organ untuk perjalanan makanan dan minumannya. Oleh karena hewan yang dihalalkan dimakan sekalipun, tetap tidak bisa dimakan kecuali dengan melalui pemotongan, selain ikan dan belalang. ${ }^{5}$

\section{B Rukun Penyembelihan}

Sebelum proses penyembelihan dilakukan, terlebih dahulu kita harus mengetahui ukunrukun dalam menyembelih. Rukun-rukun menyembelih itu adalah sebagai berikut: ${ }^{6}$

1. Penyembelih

Syarat bagi penyembelih hendaknya orang Islam atau ahli kitab (orang yang berpegang dengan kitab-kitab Allah, selain Al-qur'an) dan dilakukan dengan sengaja. Dalam Al-qur'an disebutkan

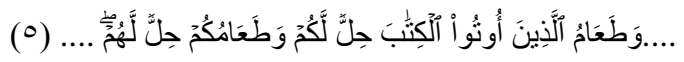

Terjemahannya: "Makanan (sembelihan) orang-orang yang diberi Al-Kitab itu halal bagimu, dan makanan kamu halal pula bagi mereka". (QS. Al-Maidah:5) ${ }^{7}$

2. Hewan Yang Disembelih

3 Yusuf Qardhawi, Halal dan Halam dalam Islam, Alih bahasa Mu'ammal Hamidy, (Surabaya: PT Bina Ilmu Surabaya, 2010), h. 60.

${ }^{4}$ Wahbah al-Zuhaili, Fiqih Islam Wa Adillatuhu, h. 585.

${ }^{5}$ Sayyid Sabiq, Fikih Sunnah, (Cet. 1; Bandung: PT Alma'arif, 1987), h. 132.

${ }^{6}$ Rohadi Abdul Fatah, Pedoman dan Tata Cara Pemotongan Hewan Secara Halal, h. 19.

${ }^{7}$ Mochtar Naim, Kompendium Himpunan Ayat-Ayat Al-qur'an Yang Berkaitan Dengan Hukum, (Jakarta: CV. Hasnah, 2001), h. 73. 
Hewan yang disembelih adalah hewan yang halal, baik halal zatnya maupun halal cara memperolehnya, bukan hasil mencuri atau menipu. Hewan yang disembelih harus disembelih pada bagian yang telah ditentukan, yaitu leher dengan memotong dua urat darah, kerongkongan, dan tenggorokannya.

3. Alat Penyembelih

Alat yang digunakan untuk menyembelih hewan harus yang tajam agar dapat mempercepat proses kematian binatang itu dan tidak terlalu menderita sewaktu disembelih. Oleh karena itu, alat yang dipakai sebaiknya terbuat dari besi dan tembaga, seperti pisau atau golok. Sementara itu, gigi, kuku, dan tulang tidak boleh dipergunakan untuk menyembelih meskipun tajam dan lancip.

4. Tujuan Penyembelihan

Penyembelihan dilakukan untuk tujuan yang diridhai Allah SWT, bukan untuk tumbal atau sajian nenek moyang, berhala, atau upacara kemusyrikan lainnya. Jika tujuannya untuk upacara atau kegiatan kemusyrikan makan hukum daging hewan tersebut menjadi haram meskipun hewannya halal dan membaca kalimat bismillahi wallahu akbar (dengan menyebut nama Allah, Allah Maha Besar) pada saat penyembelihannya.

\section{Syarat-Syarat Penyembelihan}

Proses pemotongan hewan dalam Islam haruslah mendapat perhatian yang khusus sehingga pemotongannya benar-benar sesuai dengan syariat Islam. Maka dari itu, kita harus mengetahui dan menentukan dengan jelas bagaimana proses penyembelihan, tata cara penyembelihan, niat serta yang berhubungan dengan proses penyembelihan tersebut termasuk syarat-syarat lainnya.

Secara umum syarat-syarat penyembelihan yang wajib dipenuhi bagi kehalalan mengkonsumsi daging hewan sembelihan adalah berkaitan dengan penyembelih, bagian tubuh yang disembelih, hakikat penyebutan nama Allah pada penyembelihan, alat untuk menyembelih, dan cara-cara penyembelihan hewan.

Penyembelihan dianggap sah apabila telah memenuhi syarat-syarat berikut:

1. Binatang itu hidup (mustaqirrah) diawal penyembelihannya walaupun secara dugaan saja. $^{8}$

2. Alat penyembelihannya harus tajam dan dapat mengalirkan darah.

Haram memakan daging binatang yang mati terhimpit, mati jatuh, atau ditembak dengan peluru (bukan berburu), atau disembelih dengan pisau tumpul yang tidak dapat dikeratkan melainkan semata-mata dengan kekuatan menyembelih. ${ }^{9}$

3. Menyebut nama Allah, yaitu mengucapkan,"Bismillahiwallahu Akbar" (Dengan menyebut nama Allah, Allah maha besar), atau "Bismillahi" saja.

4. Memotong tenggorakan di bagian bawah jakun (lidah kecil), serta memotong kerongkongan dan dua urat leher sekaligus.

8 Ibnu Mas'ud dan ZainalAbidin, Fiqih Madzhab Syafi'i, (Bandung: CV Pustaka Setia, 2007), h. 453.

${ }^{9}$ Ibnu Mas'ud dan ZainalAbidin, Fiqih Madzhab Syafi 'i, h. 454. 
5. Penyembelihan adalah seorang yang layak, yaitu seorang muslim berakal yang baligh atau anak-anak yang sudah mumayyiz.

6. Jika menemukan kesulitan untuk menyembelih hewan karena terjatuh kedalam sumur misalnya atau karena lepas, boleh dilakukan penyembelihan dengan menyentuhkan alat penyembelihan pada bagian tubuh manapun dari binatang tersebut yang dapat mengalirkan darahnya. ${ }^{10}$

\section{Penyembelih}

Penyembelih yaitu orang yang sudah baligh, berakal, beragama Islam baik ia seorang pria atau seorang wanita, baik muslim atau ahli kitab. Sembelihan yang dilakukan oleh orang yang menyembah berhala, orang musyrik, dan orang murtad dalam Islam hasilnya sembelihannya yaitu tidak halal. Begitu juga dengan orang pemabuk, orang gila, atau anak kecil.

Standar penyembelih yaitu: beragama Islam, sudah akil baligh, memahami tata cara penyembelihan secara syar'i dan memiliki keahlian dalam penyembelihan. ${ }^{11}$ Syarat bagi penyembelih hendaknya orang Islam atau ahli kitab (orang-orang yang berpegang dengan kitab-kitab Allah, selain Al-Qur'an) dan dilakukan dengan sengaja.

\section{E. Binatang yang Disembelih}

Binatang yang disembelih adalah binatang yang halal, baik halal zatnya maupun halal cara memperolehnya, bukan hasil mencuri atau menipu. Firman Allah SWT menyebutkan:

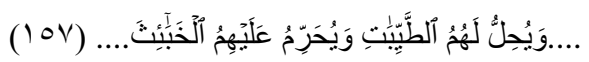

Terjemahannya:'Dan menghalalkan bagi mereka segala yang baik dan mengharamkan bagi mereka segala yang buruk.”(QS. Al-A'raf:157).

Ayat tersebut menjelaskan bahwa binatang yang disembelih itu termasuk makanan halal, bersih, dan baik. Binatang yang disembelih harus Binatang itu hidup (mustaqirrah) diawal penyembelihannya walaupun secara dugaan saja. Binatang yang boleh disembelih ada dua macam, yaitu binatang yang bisa disembelih dan binatang yang tidak boleh disembelih. Binatang yang disembelih harus disembelih pada bagian yang telah ditentukan, yaitu leher dengan memotong dua urat darah, kerongkongan dan tenggorakannya.

\section{F. Tata Cara Penyembelihan}

Adapun urutan cara menyembelihan hewan sebagai berikut: ${ }^{12}$

1. Hewan yang akan disembelih direbahkan.

2. Dilakukan dengan menghadapkan diri ke arah kiblat, begitu pula hewan yang akan disembelih.

3. Potonglah urat nadi dan kerongkongannya yang ada di kiri kanan leher, sampat putus agar lekas mati.

${ }^{10}$ Muhammad bin Shalih Al Utsaimin, Tata Cara Qurban Tuntunan Nabi, (Jogjakarta: Media Hidayah, 2003), h. 95.

11 Himpunan Fatwa Majelis Ulama Indonesia, Standar Sertifikasi Penyembelihan Halal, (Jakarta: Fatwa MUI, 2009), h. 706.

${ }^{12}$ Rohadi Abdul Fatah, Pedoman dan Tata Cara Pemotongan Hewan Secara Halal, h. 24. 
4. Saat menyembelih, membaca basmalah

Artinya: "Dengan menyebut nama Allah, Allah maha besar".

5. hewan yang lehernya agak panjang maka menyembelihnya di pangkal leher sebelah atas agar lekas mati.

6. Setelah hewan itu benar-benar mati sempurna, barulah boleh dikuliti.

\section{G. Rumah Potong Ayam}

Rumah Potong ayam (RPA) adalah komponen utama dalam usaha pemotongan ayam. Usaha pemotongan ayam ini merupakan suatu kegiatan merubah ayam hidup menjadi bentuk karkas yang siap dipasarkan atau dimasak (ready to cook). Kegiatan usaha di rumah potong ayam tidak lepas dari aspek pemasaran. Salah satu aspek pemasaran yang paling penting dalam usaha jasa rumah pemotongan ayam adalah kualitas pelayanan yaitu kemampuan perusahaan untuk memberikan pelayanan sebaik mungkin kepada pelanggan baik dalam bukti fisik, kehandalan produk/jasa, ketanggapan karyawan, jaminan serta empati karyawan. Perusahaan yang memiliki pelayanan yang bagus kepada konsumennya akan memberikan kontribusi sangat besar terhadap perkembangan perusahaan itu sendiri baik dari segi profitabilitas maupun image perusahaan di mata konsumen. ${ }^{13}$

\section{METODE PENELITIAN}

\section{HASIL PENELITIAN}

\section{PENUTUP}

\section{Kesimpulan}

Praktik penyembelihan dan pengolahan ayam di rumah potong ayam di pasar Sentral Pekkabata Kecamatan Polewali memiliki tahapan yaitu: pengambilan ayam dari kandang, mengambil ayam satu per satu yang sudah dikeluarkan dari kandang untuk disembelih, membaca "Bismillah" dalam hati dan ayam disembelih dibagian leher dengan menggunakan pisau yang tajam, tahap pengolahan ayam setelah disembelih yaitu: perendaman ayam di air panas yang tidak mendidih, pencabutan bulu menggunakan mesin bubut pencabut bulu ayam, pengeluaran jeroan atau organ dalam, pencucian ayam, pemotongan daging ayam dan pengemasan daging ayam.

Penyembelihan dan pengolahan ayam di pasar Sentral Pekkabata Kecamatan Polewali masih banyak belum sesuai dengan Undang-Undang Nomor 33 Tahun 2014. Karena semua rumah pemotongan hewan yang ada di Kabupaten Polewali Mandar belum mempunyai sertifikat halal. Dan mengenai syarat yang harus dipenuhi untuk

\footnotetext{
${ }^{13}$ Bagus Purnomo Eko, Desain Manual Sistem Jaminan Halal Terintegrasi Standar Rumah Pemotongan Unggas (Studi Kasus di Rumah Potong Ayam Wataslim), (Bogor: Bogor, 2016), h. 2 .
} 
penyembelihan halal menurut Peraturan Pemerintah Nomor 95 Tahun 2012 Tentang Kesehatan Masyarakat Veteriner dan Kesejahteraan Hewan disebutkan dalam pasal 8 dan pasal 9 masih ada rumah potong ayam yang belum menerapkan hal demikian. Selain itu dalam proses pengolahan ayam, ke empat rumah potong ayam di Pasar Sentral Pekkabata Kecamatan Polewali tidak adanya pemisahan antara ayam yang gagal disembelih dan yang berhasil disembelih. Dan ke empat rumah potong ayam di pasar Sentral Pekkabata Kecamatan Polewali dalam proses penyembelihan dan pengolahan ayam masih dilakukan disatu lokasi dimana tidak ada pembagian antara daerah kotor dan daerah bersih.

\section{DAFTAR PUSTAKA}

Departemen Agama Republik Indonesia. Al-Qur'an dan Terjemahannya.

Qur'an in Word. Al-Qur'an dan Terjemahannya. Versi 1.3.

Anwar, Ridho. Pengaruh Penyembelihan Halal Terhadap Perilaku Konsumen (Studi Kasus Rumah Potong Ayam Alfa Broiler Yosodadi Metro Timur). Skripsi. Metro: Fakultas Ekonomi dan Bisnis Islam. 2017.

Badan Standarisasi Nasional. Standar Nasional Indonesia (SNI) 01-6160-1999 Rumah Pomotongan Unggas.

Bungin, Burhan. Penelitian Kualitatif. Cet. II;Jakarta: Kencana. 2012.

Dienillah, Nurul Izzah. Tinjauan Hukum Islam Terhadap Jual Beli Ayam Potong Sembelihan Orang Fasiq Menurut Iman Syafi'i (Studi Kasus Jual Beli Ayam di Pasar Bandarjo Ungaran). Skripsi. Semarang: Fakultas Syariah dan Hukum UIN Walisongo Semarang. 2015.

Eko, Bagus Purnomo. Desain Manual Sistem Jaminan Halal Terintegrasi Standar Rumah Pemotongan Unggas (Studi Kasus di Rumah Potong Ayam Wataslim). Bogor: Bogor. 2016.

Fatah, Rohadi Abdul. Pedoman dan Tata Cara Pemotongan Hewan Secara Halal. Cet. III; Jakarta: Direktur Urusan Agama Islam dan Pembinaan Syari'ah. 2010.

Himpunan Fatwa Majelis Ulama Indonesia. Standar Sertifikasi Penyembelihan Halal. Jakarta: Fatwa MU Indonesia. 2009.

Karim, Adiwarman. Ekonomi Mikro Islam Edisi Lima. Jakarta: PT. Raja Grafindo Persada. 2007.

Majelis Ulama Indonesia. Himpunan Fatwa Mejelis Ulama Indonesia Sejak 1975. Jakarta: Erlangga. 2011.

Mas'ud, Ibnu dan Zainal Abidin.Fiqih Madzhab Syafi'i. Bandung: CV Pustaka Setia.2007.

Moleong, Lexy J. Metodologi Penelitian Kualitatif. Bandung: Remaja Kosda Karya. 2002.

Musa, Kamil. Ensiklopedia Halal Haram dalam Makanan dan Minuman. Solo: Ziyad Visi Media, 2006. 
Naim, Mochtar. Kompendium Himpunan Ayat-Ayat Al-qur'an Yang Berkaitan Dengan Hukum. Jakarta: CV. Hasnah. 2001.

Penjelasan Undang-Undang Nomor 33 Tahun 2014 tentang Jaminan Produk Halal.

Peraturan Pemerintah Nomor 95 Tahun 2012 Tentang Kesehatan Masyarakat Veteriner dan Kesejahteraan Hewan.

Prastowo, Andi. Metode Penelitian Kualitatif dalam Perspektif Rancangan Penelitian. Cet. 1; Jogjakarta: AR-RUZ MEDIA. 2011.

Qardhawi, Yusuf. Halal dan Halam dalam Islam, Alih bahasa Mu'ammal Hamidy. Surabaya: PT Bina Ilmu Surabaya. 2010.

Ritonga, Novita Nanda Sari BR. Pemotongan Ayam Oleh Pedagang Ayam Di Pasar Tradisional Sukaramai Medan Area Kota Medan (Tinjauan Menurut Standar Sertifikasi Penyembelihan Halal Menurut Fatwa MUI No. 12 Thn 2009). Skripsi. Medan: Fakultas Syari'ah dan Hukum. 2018.

Sabiq, Sayyid. Fikih Sunnah. Cet. 1; Bandung: PT Alma'arif. 1987.

Sugiyono. Metode Penelitian Kuantitatif, Kualitatif, dan Kombinasi (Mixed Methods). Bandung: Alfabeta. 2013.

Sugiyono. Metode Penelitian Kuantitatif, Kualitatif dan R\&D. Cet. 8; Bandung: Alfabeta. 2009.

Surahmad, Winamo. Dasar dan Teknik Research. Bandung: CV Tarsito. 1972.

Sutopo. Metodologi Penelitian Kualitatif. Surakarta: UNS. 2006.

Undang-Undang Nomor 33 Tahun 2014 tentang Jaminan Produk Halal.

Al-Utsaimin Muhammad bin Shalih. Tata Cara Qurban Tuntunan Nabi. Jogjakarta: Media Hidayah. 2003.

al-Zuhaili, Wahbah. Fiqih Islam Wa Adillatuhu. Jilid 4. Cet. 10; Damaskus: Darul Fikr. 2007. 